\title{
再生絹フィブロインの溶液物性に及ぼす塩の影響
}

\author{
藤井恵子 ${ }^{\dagger}$, 佐藤美和子 \\ 山形大学教育学部
}

\section{Effect of Salts on Solution Properties of Silk Fibroin Regenerated}

\author{
Keiko FUJII ${ }^{\dagger}$ and Miwako SATO
}

\author{
Faculty of Education, Yamagata University, Kojirakawa-machi, Yamagata-shi 990-8560, Japan
}

The effects of added salts on the solution properties of silk fibroin in water were investigated by the static light scattering method. Silk fibroin was extracted from sericin-removed yarn by $35 \%$ calcium chloride at $98^{\circ} \mathrm{C}$ for $6 \mathrm{~h}$. Fibroin solution was obtained by dialysis of the resultant extract against distilled water at $4^{\circ} \mathrm{C}$. All the experiments were done using $6 \%$ fibroin solutions at $25^{\circ} \mathrm{C}$. Monovalent salts such as $\mathrm{NaCl}$ and $\mathrm{KCl}$ induced the formation of disorderly structure via the aggregation of fibroin molecules. On the other hand, the phase separation was observed in the presence of divalent salts such as $\mathrm{CaCl}_{2}$ and $\mathrm{MgCl}_{2}$. This phase separation may be attributed to the intermolecular interaction of fibroin strengthened by the bridging effects of divalent salts. The relative viscosity of fibroin solution depended on the salts, but did not correspond to the difference in the valence of salts and the solution properties of fibroin. These results indicated that the divalent salts-induced phase separation of fibroin solution occurred in the micro-region within colloidal particles thereby not affecting viscosity strongly.

Key words: silk fibroin, solution structure, phase separation, light scattering

\section{1. 腥言}

1994 年 12 月にわが国政府によって環境基本計画が決 定され，「日常生活一般による環境への負荷を認識し， 現在の経済社会システムや生活様式を根本から見直すこ と」が今後の環境保全の基本理念の一つとして据えら れ，2000年 12 月には，「物質循環をできる限り確保す ることによって，環境への負荷をできる限り少なくし， 循環を基調とする社会システムを実現すること」が長期 目標として揭げられた，我々は，環境から食糧や原料な どの資源を採取して, 社会生活を営み, その過程で出る 多くの不用物を廃棄物として環境に排出している。この 不用物の排出が環境復元能力の範囲を越え, 地球環境 に甚大な悪影響を及ぼすことが懸念され，資源を有効に 利用するとともに廃棄物をできる限り減らす努力が求め られている.

わが国の伝統産業の一つである絹織物業界では, 製造工 程で生じる屑絹・屑糸の廃棄物処理が大きな問題となって いる. そのため, 絹織・亘糸業界から屑絹・屑糸から精 製した絹フィブロインの食品素材としての利用を困る動

(受付 2000 年 9 月 4 日, 受理 2001 年 2 月 19 日)

$\dagger$ †990-8560 山形市小白川町 1-4-12

Fax; 023-628-4353, E-mail; ep250@kdw.kj.yamagata-u.ac.jp
きが始まっている．絹フィブロインは絹織物産業におけ る残系から精製するため, これを食品素材として利用す ることは原材料費が安価であるばかりでなく資源循環の 観点からも「地球環境にやさしい」ということができる. また, 絹フィブロインは 18 種類のアミノ酸から構成さ れ, 主なものはグリシン, アラニン, セリン, チロシンで ある.グリシン，セリンには血中コレステロール濃度を 低下させる作用が, アラニンには肝蔵のアルコール代謝 を促進させる作用が, またチロシンは痴朵症予防, パー キンソン病に効果があることが明らかにされている[1-3]. このように, 絹フィブロインの食品への応用技術は, 環 境保全と食品機能, おいしさの 3 つの観点からの要請を すべて満たす食品を創製する技術と言える。このような 絹フィブロインの食品への応用は, 東京農工大学の平林 らによって提案され[4,5], 絹入りうどんや絹プロティ ン入りドリンクョーグルトなどとして商品化されている [6]. しかし, これまでの応用例は, 既存の食品に粉末 化した絹フィブロインを単に添加したものにすぎず，絹 のイメージを商品に付加することを目的としたものばか りである.

絹フィブロインは, セリシンとともに絹繊維の成分で あり, 繊維学の観点から構造化学的な研究がなされ，ま た， $\alpha$-ヘリックスがなく $\beta$ 構造が多いモデルタンパク 
質としてタンパク質化学的に研究が進んできた。しかし， 現在のところ絹フィブロインは食品素材として認識され ていないため, その食品化学的, 調理科学的研究は少な い. 絹フィブロインが食品素材として認識されるために は, 絹フィブロインの調理特性を最大限に生かした高度 な利用法を開発して食品素材としての利用分野をさらに 拡大することが必要である. 絹フィブロインは $\beta$ 構造が 多いタンパク質であり， $\beta$ 構造が規則的に配向しやすい という特徴がある[7]。濃度, 温度を適当に選ぶことに よってゲル化するとともに，優れた泡沫特性を有してい ることが示された[8]. そして, 絹フィブロインの泡沫 安定化機能を利用して, 小麦粉を用いない米粉のスポン ジケーキが開発された[9].

絹フィブロインは，その一次構造が主に-Gly-Ala-GlyAla-Gly-Ser-の繰り返し構造を有するタンパク質である [10]. 絹フィブロインの分子形態には 3 種類知られてお り[11-13], その一つはらせん構造と考えられ, シルク I またはフィブロイン $\boldsymbol{\alpha}$ 型と呼ばれる結晶形態をとる. 第二は分子が伸びた形で, タンパク質分子は逆平行 $\beta$ シー ト構造をとっていると考えられ，この形をとるシルクは シルク II 型またはフィブロイン $\beta$ 型と呼ばれる結晶形態 をとる。第三が特定の形をとらないランダムコイルであ る。これは非結晶性である。最近になって，気液界面に おいて疎水性のアラニン残基と親水性のセリン残基が配 向して三重らせん構造をとっていると考えられるシルク III という新しい形態が見つかっている[14].

再生絹フィブロインを食品素材として利用する場合に は, 透析後の溶液が原材料となる.タンパク質や多糖類 のような高分子が相互作用するとコロイド粒子が生成 し, 溶液内でのコロイド状態が反映された溶液構造は加 工性に大きな影響を与えると考えられる。コロイドの溶 液構造を把握する方法には, 電子顕微鏡観察, 各種散 乱法などが知られている. 電子顕微鏡観察では直接的な 状態観察が可能な方法であるが, 溶液試料を溶液状態 で観察することは不可能である。一方, 散乱法は溶液試 料の非破壊測定が可能である. 散乱法によって得られる

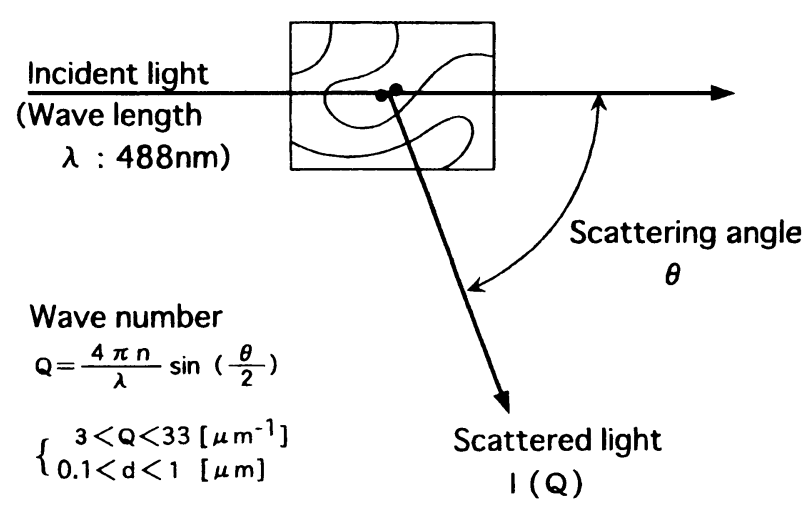

Fig.1 Diagram of light scattering experiment.
結果は, 散乱体の空間分布に関するフーリエ空間での情 報の反映であるので, 波数 $Q$ (光散乱の場合は, $Q=$ $4 \pi n \sin (\theta / 2) / \lambda ; n$ : 溶媒の屈折率, $\theta$ : 散乱角, $\lambda$ : 入射光の波長）が小さい領域の結果は長距離空間構造 に関する情報を，Qが大きい領域の結果は短距離空間構 造に関する情報を与える（Fig. 1)。したがって，食品 素材の溶液構造を検討する手段として散乱実験は有用と 考えられる。本研究では, 再生絹フィブロイン溶液の溶 液構造に及ほす塩添加の影響を, 光散乱法を用いて検討 した。

\section{2. 実験}

\section{1 再生絹フィブロイン溶液の調製}

廃絹系（松岡機業 (株), 鶴岡市) を $1 \%$ 炭酸水素ナ トリウム中で煮沸洗浄する操作を数回繰り返してセリシ ンを除去したのち，35\%塩化カルシウム溶液に移し， $98{ }^{\circ} \mathrm{C} て ゙ 6$ 時間加熱溶解させた。この溶液を $4{ }^{\circ} \mathrm{C}$, 蒸留 水中にて透析・脱塭し, 滤過することにより絹フィブロ イン溶液を得た。絹フィブロイン溶液の濃度は $6 \%$ に調 整し，実験に供した。

\section{2 光散乱測定}

$6 \%$ 絹フィブロイン溶液の光散乱測定は, 光源として アルゴンレーザー $(\lambda=488 \mathrm{~nm})$ を備えた光散乱光度

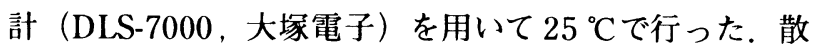
乱角は $10^{\circ}$ 刻みで $10^{\circ}$ から $150^{\circ}$ までとした。

\section{3 粘度測定}

$6 \%$ 絹フィブロイン溶液の粘度は, オストワルド粘度

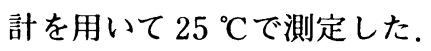

\section{3. 結果および考察}

\section{1 再生絹フィブロイン溶液の光散乱}

絹フィブロイン溶液の光散乱測定の結果を Fig. 2 に 示す. 縦軸が散乱光強度 $I(Q)$, 横軸が波数 $Q$ である. グラフには, 散乱体間干涉によるピーク $Q_{m}$ が認められ た. Hossain \& Nemoto [15] による希薄溶液（0.177$0.386 \mathrm{~g} / \mathrm{L}$ の濃度範囲）での光散乱測定ではこのよう なピークは観測されていない.この結果から, 脱塩後の 6\%絹フィブロイン溶液中においては, 濃度が高いため 絹フィブロイン同士の相互作用によって規則的な空間構 造が形成されていることが明らかとなった。このような ピークは, 相分離系で広く観測されており[16-20]，一 般的にはラメラ状相分離構造の面間隔 $d$ と,

$$
d=2 \pi / Q_{m}
$$

と関係づけられる[21]. 絹フィブロインは, 疎水性のア ラニン残基，親水性のセリン残基とからなる界面活性剤 


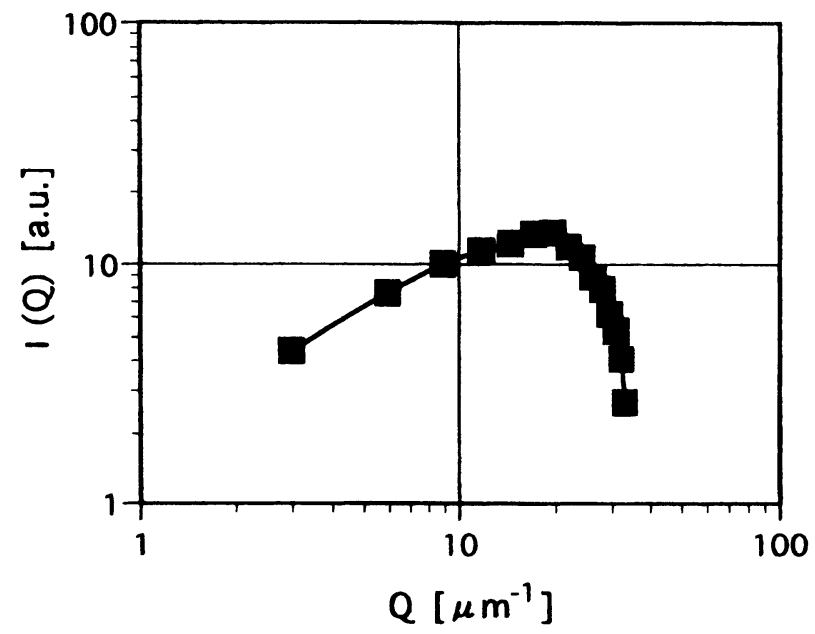

Fig.2 Light scattering intensity of silk fibroin solution.
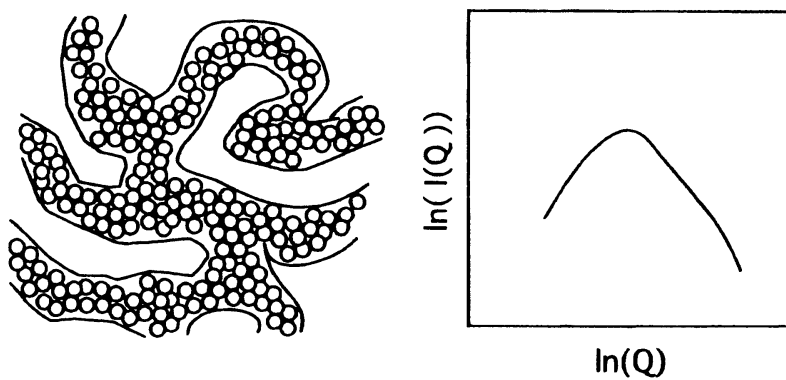

Fig.3 Schematic illustration of phase separation structure.

である[22] ことを考えあわせると，絹フィブロインの分 子間相互作用の結果生じた会合体がラメラ状に集合した 溶液構造をとり，これが干渉を起こしていることが可能 性として考えられた（Fig. 3).dは $0.32 \mu \mathrm{m}$ となり， $\mathrm{DMSO} / \mathrm{H}_{2} \mathrm{O}$ 系での PVAのゲル化の初期過程での相分 離での $0.57 \mu \mathrm{m}[18]$ という值と近いことがわかった.

\section{2 絹フィブロイン溶液の溶液構造に及ぼす添加塩の \\ 影響}

絹フィブロインは, 溶液中である配向構造をとってい ることがわかったので, 塩共存下での溶液構造について 知見を得るために, $\mathrm{NaCl}, \mathrm{KCl}, \mathrm{CaCl}_{2}, \mathrm{MgCl}_{2}$ の 4 種 の塩を選び光散乱測定を行った。

1 価の塩である $\mathrm{NaCl}, \mathrm{KCl}$ (濃度はともに $200 \mathrm{mM}$ ） を添加すると, Fig. 2 の結果と異なり, 散乱光強度の 波数依存性は単調減少するカーブとなり，ピークは認め られなかった（Figure not shown）。このことから， $\mathrm{NaCl}, \mathrm{KCl}$ 共存下では純水中で形成される配向構造が 消失していることが示された. $\mathrm{NaCl}$ を添加したフィブ ロイン溶液の散乱光強度の結果を Guinier plot $\left(\ln I(Q)\right.$ vs. $\left.Q^{2}\right)$ したグラフをFig. $4(\mathrm{~A})$ に, DebyeBueche plot $\left(I(Q)^{-1 / 2}\right.$ vs. $\left.Q^{2}\right)$ したグラフを Fig. $4(\mathrm{~B})$ に示す.いずれのプロットにおいても $Q$ の小さい領域
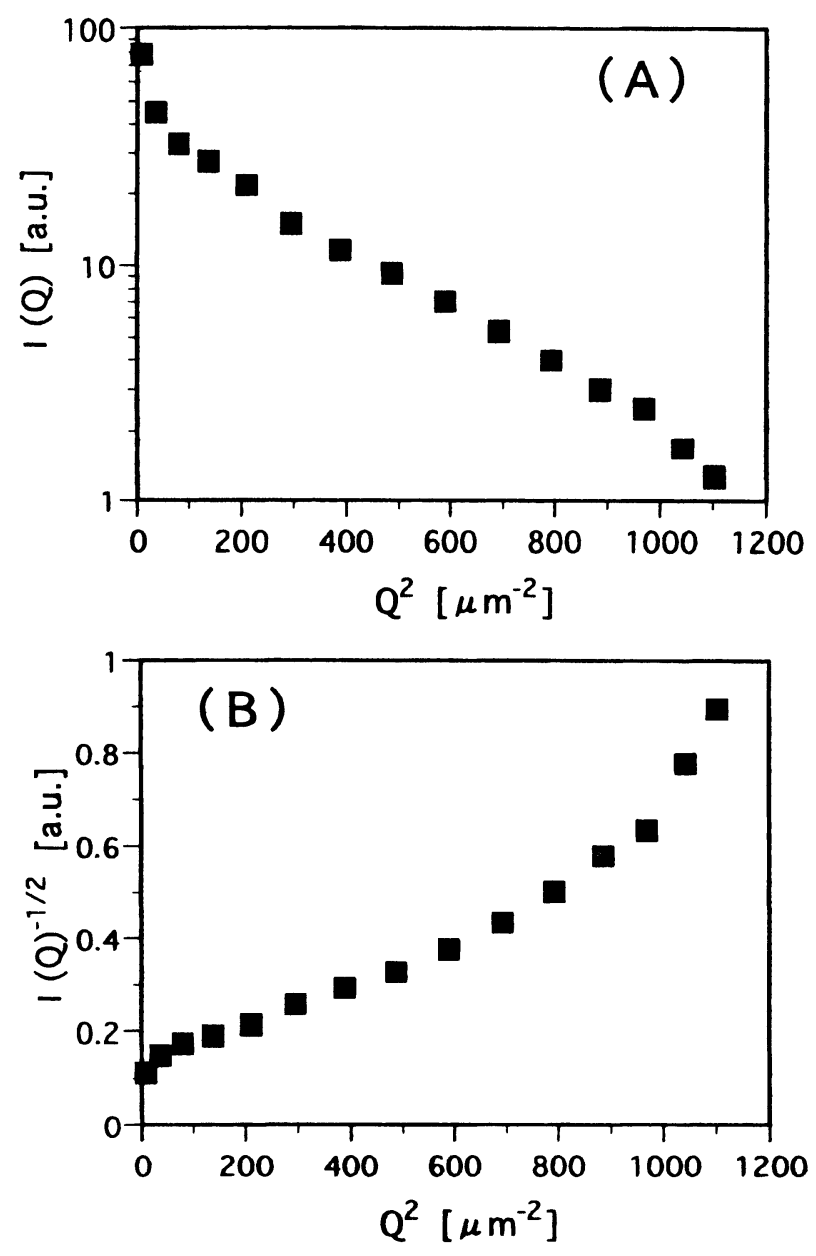

Fig.4 Guinier plot (A) and Debye-Bueche plot (B) of silk fibroin in $200 \mathrm{mM} \mathrm{NaCl}$ solution.

には直線性は認められなかった。したがって, 分散粒子 の大きさに関して解析するためには, 粒子の多分散性を 仮定して逐次差分を行いサイズ分布を求める方法 [23] を用いる必要があると思われた。 $\mathrm{KCl}$ 添加の系において も同様であった。

単調減少する散乱カーブにおいては, 系内にフラクタ ル構造を有する散乱体が存在するとき，そのスケール (物体全体の大きさより充分小さく，構成単位よりは大 きなスケール）に対応して, 散乱光強度が波数 $Q$ のべ き乗則：

$$
I(Q) \propto Q^{-a}
$$

に従う。フラクタルの概念はPeleg \& Normand [24] によって食品分野に持ち込まれ，日本においては鈴木\& 矢野 [25] から研究が始まった。散乱実験の結果は, マ ルチフラクタルの概念で解析される[26-29]. すなわち, 式(2) における指数 $a$ が 1 〜 3 の值をとるとき「質量フ ラクタル」と呼ばれ, そのフラクタル次元は $D_{\mathrm{M}}=a$ と なる. $a$ が 3 〜 の值をとるとき「表面フラクタル」と 呼ばれ，そのフラクタル次元は $D_{\mathrm{S}}=6-a$ となる. Suzuki et al. [30] は, デンプンの小角 $\mathrm{X}$ 線散乱を測定 し, 表面フラクタル次元と質量フラクタル次元の観点か 

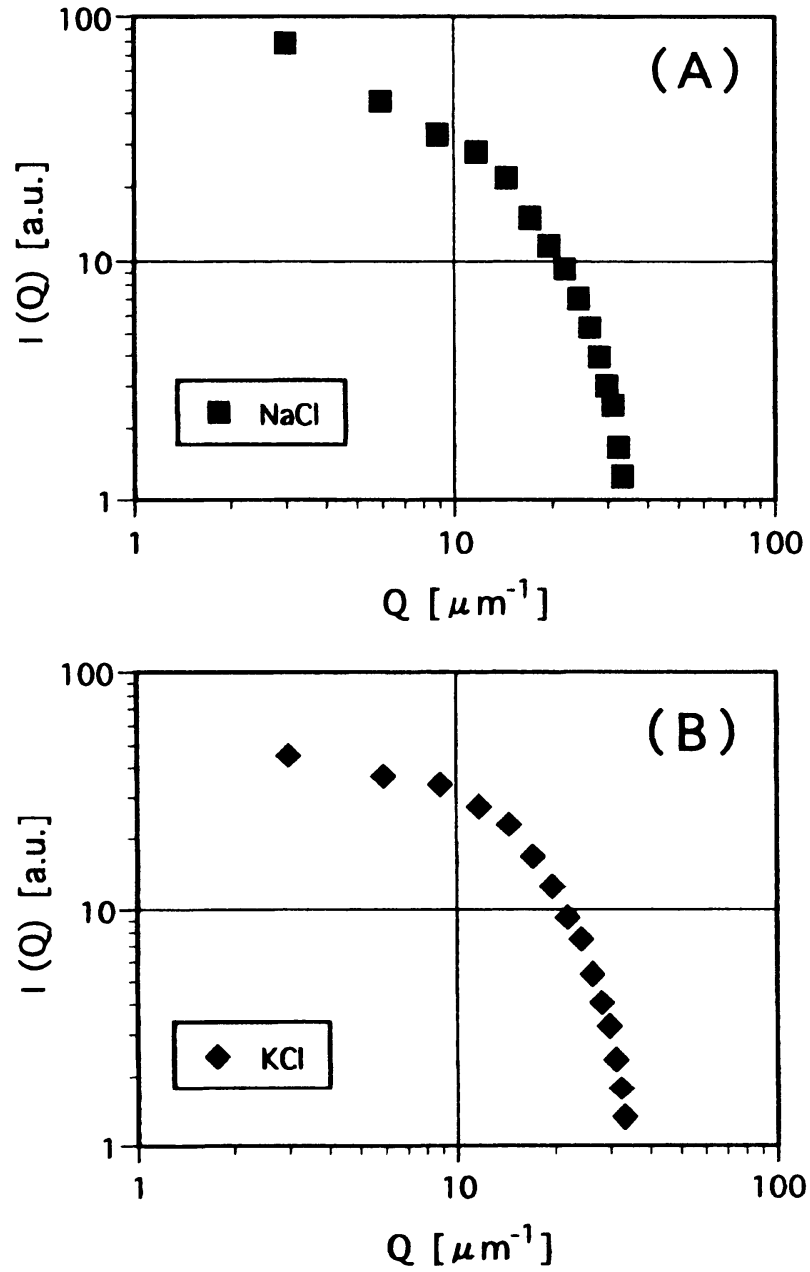

Fig.5 Light scattering intensity of silk fibroin in $200 \mathrm{mM} \mathrm{NaCl}$ (A) and $\mathrm{KCl}(\mathrm{B})$ solutions.

ら膨潤や糊化による変化について検討している．Fig．5 は， $\mathrm{NaCl}$ および $\mathrm{KCl}$ を添加した絹フィブロイン溶液に おける散乱カーブの両対数プロットである. 両対数プロ ットの傾きがー1〜 - 3 あるいはー $3 \sim-4$ となる直 線性を示す波数領域を探索したところ，そのような領域 は認められなかった。これらの結果から，1 価の塩の存 在によって不規則な凝集構造が形成されているが，0.1 $1 \mu \mathrm{m}$ のスケール領域ではフラクタル様構造は生じてい ないことが示唆された。 また, $\mathrm{NaCl} と \mathrm{KCl}$ の影響の差 はそれほど認められなかった。

次に, 2 価の塩である $\mathrm{CaCl}_{2}$ および $\mathrm{MgCl}_{2}$ (濃度はと もに $200 \mathrm{mM}$ ）を添加すると，無添加の結果と同様に 散乱カーブに極大が認められた（Fig．6）。式(1)を用 いて相分離の特徴的な大きさを求めると, $\mathrm{CaCl}_{2}$ を添加 した系では $0.36 \mu \mathrm{m}, \mathrm{MgCl}_{2}$ を添加した系では 0.53 $\mu \mathrm{m}$ であった。 以上の結果から, $\mathrm{NaCl}$ と $\mathrm{KCl}$ は, 透析 後の純水中で形成されていた相分離構造を破壊するのに 対して, $\mathrm{CaCl}_{2}$ と $\mathrm{MgCl}_{2}$ は相分離構造を破壊しないこ とが明らかとなった。これらの結果から，塩の存在は分子 間の静電的相互作用を弱めるが，2 価の塩によるブリッ ジ効果が分子間相互作用を促し，結果として相分離構
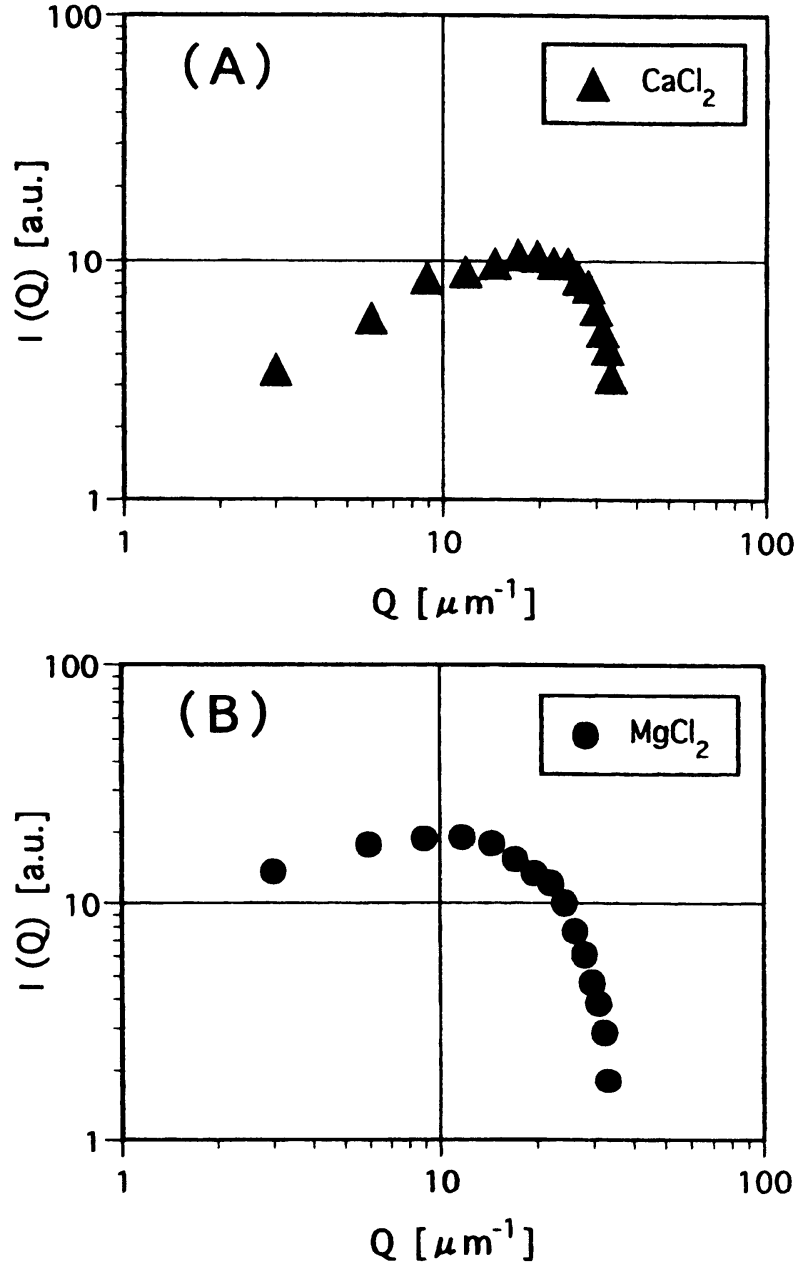

Fig.6 Light scattering intensity of silk fibroin in $200 \mathrm{mM} \mathrm{CaCl}$ (A) and $\mathrm{MgCl}_{2}$ (B) solutions.

造が維持されたと考えられた。そして，相分離ドメイン の特徴的な大きさは， $0.3 \sim 0.6 \mu \mathrm{m}$ 程度と推算され た。また，いずれの塩の場合も，散乱カーブは波数 $Q$ が大きい領域において式(2)のべき乗則が成り立ち，指 数 $a$ は 6 に近い值となった。相分離構造に由来する散 乱カーブは, Furukawa [31]により

$$
I(X)=I\left(\frac{Q}{Q_{m}}\right) \propto \frac{X \delta}{\frac{\gamma}{\delta}+X(\gamma+\delta)}
$$

が得られている.ここで，X は規格化された波数である $\left(X=Q / Q_{m}\right)$. 二成分混合系の臨界点に近い条件では, $\delta=2, \gamma=6$ と予想されており，このとき $Q$ が大きい (すなわち，Xが大きい）領域では散乱カーブが波数 の一 6 乗となる. $\mathrm{CaCl}_{2}$ あるいは $\mathrm{MgCl}_{2}$ 共存下の絹フィ ブロイン溶液の相分離構造は, Furukawa の予測と近い 結果であった。

\section{3 綃フィブロイン溶液の相対粘度に及ぼす添加塩の 影響}

$6 \%$ 絹フィブロイン溶液について粘度を測定した （Table 1）。相対粘度は添加塩の種類に依存し， 
Table 1 Relative viscosity of $6 \%$ silk fibroin solution.

\section{Added salt}

Relative viscosity

\begin{tabular}{ll}
\hline & \\
none & 2.60 \\
$\mathrm{NaCl}$ & 2.76 \\
$\mathrm{KCl}$ & 2.90 \\
$\mathrm{CaCl}_{2}$ & 2.96 \\
$\mathrm{MgCl}_{2}$ & 2.88 \\
\hline
\end{tabular}

$\mathrm{CaCl}_{2}>\mathrm{KCl}>\mathrm{MgCl}_{2}>\mathrm{NaCl}$ の順となった。光散乱 の結果から, 1 価の塩と 2 価の塩では溶液特性について は顕著な差が見られたが，相対粘度に関しては溶液特性 に対応した依存性は認められなかった。粘度はコロイド 粒子の流体力学的半径に強く依存することを考え合わせ ると, $\mathrm{CaCl}_{2}$ と $\mathrm{MgCl}_{2}$ 添加系において認められた相分 離構造はコロイド粒子内の微小な領域での相分離である ことが示唆された。

再生絹フィブロインは適当な条件でゲル化することが 知られている.ゲルのレオロジー特性はその内部構造に 依存するので，塩の種類が異なると形成されるゲル内部 構造に差が生じ，結果として弾性率や破断応力に大きな 影響を及ぼすと考えられる。本研究で絹フィブロイン溶 液の溶液構造が 1 価の塩の場合と 2 価の塩の場合とでか なり異なった構造であることが示された。タンパク質ゲ ルのレオロジー特性に及ぼす添加塩の影響は単純でない ことが知られている[32-34]. 例えば，酸性大豆タンパ ク質ゲルではその破断応力に及ぼす $\mathrm{NaCl}$ の効果は $\mathrm{pH}$ に依存しており， $\mathrm{NaCl}$ の添加によって破断応力が大き くなることもあれば小さくなることもある[34]．ゲル化 前の溶液状態における構造の違いが最終的なゲル構造に 影響を与えている可能性は充分に考えられる. 今後，絹フ イブロインのゲルを調製し，溶液構造の観点からレオロジ 一特性を検討していく予定である。また，加工過程にお いては調味料や不純物として様々な塩が共存することが 想定されるため,さらに塩の種類や $\mathrm{pH}$ を変化させて体 系的にとらえることも重要であると思われる.

\section{4. 結 論}

食品素材の溶液構造に関する知見を得る一つの方法とし て光散乱実験に注目し，絹フィブロイン溶液に適用した。

絹フィブロイン分子の溶液中での存在状態は, 共存す る塩の種類によって異なり，1価の塩が共存している場 合には，凝集によって不規則な溶液構造をとっていた。 これは，塩の存在によって静電的相互作用が弱まった結
果と考えられた。この凝集構造はフラクタルではなかっ た。これに対し 2 価の塩が共存している場合には，1 価 の塩の場合と異なり相分離が起こっていた。

$6 \%$ 絹フィブロイン溶液について粘度を測定したとこ ろ，1価の塩と 2 価の塩では溶液構造については顕著な 差が見られたにもかかわらず，相対粘度に関しては溶液 構造に対応した依存性は認められなかった。粘度はコ口 イド粒子の流体力学的半径に強く依存することを考え合 わせると, $\mathrm{CaCl}_{2}$ と $\mathrm{MgCl}_{2}$ 添加系において認められた 相分離構造はコロイド粒子内の微小な領域での相分離で あることが示唆された。

\section{謝辞}

本研究の一部は, 平成 11 年度 (財) ソルト・サイエン 又研究財団研究助成によって行ったものである.

\section{引用文 献}

1) 平林潔, 陳開利, 勢籏毅; 絹フィブロインの食品素材として の応用, New Food Industry, 33 (11)，1-4 (1991).

2）平林潔；絹を食べる 機能性食品に変身，化学，47 (8), 530533 (1992).

3）平林潔, 平岩陽一; 絶を食べる, New Food Industry, 35 (1), 17-21 (1993).

4) 平林潔, 渡辺誠, 鈴木誠; 絹のゲル化とその応用 (食品), 繊維学会誌, 45 (6)，263-267 (1989).

5）平林潔；絹の食品化，月刊フードケミカル，1，41-45 (1990).

6) 平林潔；「シルクを食べる」, 高輪出版社, 1996, p. 14.

7）橮口浩三 ; 改訂蛋白質機能の分子論」, 学会出版センター, 1990, p. 31.

8）平尾和子, 木村由里子, 五十嵐喜治; 絹糸から調製した フィブロイン溶液の起泡特性とスポンジヶーキへの応用, 食 科工誌, 45, 692-699 (1998).

9）藤井恵子, 高橋貞幸, 木内瑠美子; 絹フィブロインと複合化 した米粉のスポンジケーキ 調製とその物性, 食科工誌, $\mathbf{4 7}$, 363-368 (2000).

10) F. Lucas, J. T. B. Shaw, S. G. Smith; The silk fibroins, Adv. Protein Chem., 13, 107-242 (1958).

11) O. Kratky, E. Schauenstein, A. Sekora; An unstable lattice in silk fibroin, Nature, 165, 319-320 (1950).

12) O. Kratky; An x-ray investigation of silk fibroin, Trans. Faraday Soc., 52, 558-570 (1956).

13) T. Asakura, A. Kuzuhara, R. Tabata, H. Saito; Conformation characterization of Bombyx mori silk fibroin in the solid state by high-frequency ${ }^{13} \mathrm{C}$ cross polarization-magic angle spinning NMR, x-ray diffraction, and infrared spectroscopy, Macromolecules, 18, 1841-1845 (1985).

14) R. Valluzzi, S. P. Gido, W. Zhang, W. Muller, D. L. Kaplan; 
Trigonal crystal structure of Bombyx mori silk incorporating a threefold helical chain conformation found at the air-water interface, Macromolecules, 29, 8606-8614 (1996).

15) K. S. Hossain, N. Nemoto; Dynamic and static light scattering of dilute aqueous solutions of silk fibroin collected from Bombyx mori silkworms, Langmuir, 15, 4114-4119 (1999).

16) B. S. Kim, T. Chiba, T. Inoue; Phase separation and apparent phase dissolution during cure process of thermoset/thermoplastic blend, Polymer, 36, 67-71 (1995).

17) F. Mallamace, N. Micali, S. H. Chen; Spinodal decomposition in systems containing surfactant molecules, Physica A, 236, 149-161 (1997).

18) T. Kanaya, H. Takeshita, Y. Nishikoji, M. Ohkura, K. Nishida, K. Kaji; Micro- and mesoscopic structure of poly (vinyl alcohol) gels determined by neutron and light scattering, Supramol. Sci., 5, 215-221 (1998).

19) G. D. Merfeld, D. R. Paul; Light scattering characterization of tetramethyl polycarbonate blends with polystyrene and with styrene-pentabromobenzyl acrylate copolymers, Polymer, 41, 649-661 (2000).

20) A. Ramanujam, K. J. Kim, T. Kyu; Phase diagram, morphology development and vulcanization induced phase separation in blends of syndiotactic polypropylene and ethylene-propylene diene terpolymer, Polymer, 41, 5375-5383 (2000).

21) T. Hashimoto, "Progress in Pacific Polymer Science," vol. 2, Y. Imanishi ed., Springer, Berlin, 1992, p. 175.

22) R. Valluzzi, S. P. Gido, W. Muller, D. L. Kaplan; Orientation of silk III at the air-water interface, Int. J. Biol. Macromol., 24, 237-242 (1999).

23) L. E. Alexander; "X-Ray Diffraction Methods in Polymer
Science," Wiley-Interscience, New York (1969).

24) M. Peleg, M. D. Normand; Characterization of the reggedness of instant coffee particle shape by natural fractals, J. Food Sci., 50, 829-831 (1985).

25）鈴木徹, 矢野俊正 ; フラクタル概念に基づく粉砕エネルギー 則の統一的考察, 粉体工学会誌, 26, 99-102 (1989).

26) G. L. Squires; "Introduction to the Theory of Thermal Neutron Scattering," Cambridge University Press, London (1978)

27) D. W. Schaefer, J. E. Martin; P. Wiltzius, D. S. Cannell; Fractal geometry of colloidal aggregates, Phys. Rev. Lett., 52, 2371-2374 (1984).

28) D. W. Schaefer, K. D. Keefer; Fractal geometry of silica condensation polymers, Phys. Rev. Lett., 53, 1383-1386 (1984).

29) A. J. Hurd, D. W. Schaefer, J. E. Martin; Surface and mass fractals in vapor-phase aggregates, Phys. Rev. A: Gen. Phys., 35, 2361-2364 (1987).

30) T. Suzuki, A. Chiba, T. Yano; Interpretation of small angle Xray scattering from starch on the basis of fractals, Carbohydr. Polymers, 34, 357-363 (1997).

31) H. Furukawa; A dynamic scaling assumption for phase separation, Adv. Phys., 34, 703-750 (1985).

32) A. Visser, A. Thomas; Soya protein products-their processing, functionality and application aspects, Food Rev. Int., 3, 1-32 (1987).

33) M. K. McMindes; Applications of isolated soy protein in lowfat meat products, Food Technol., 45 (12), 61-64 (1991).

34) M. C. Puppo, M. C. Anon; Rheological properties of acidic soybean protein gels: Salt addition effect, Food Hydrocoll., 13, 167-176 (1999). 